\title{
Late Pliocene climate changes documented in seismic and palynology data at the southwest African Margin
}

\author{
Estella Weigelt $^{\mathrm{a}, *}$, Lydie Dupont ${ }^{\mathrm{b}}$, Gabriele Uenzelmann-Neben ${ }^{\mathrm{a}}$ \\ a Alfred Wegener Institute for Polar and Marine Research, P.O. Box 120161, 27515 Bremerhaven, Germany \\ ${ }^{b}$ Geosciences University of Bremen, P.O. Box 330440, D-28334 Bremen, Germany
}

\section{A R T I C L E I N F O}

\section{Article history:}

Received 11 September 2007

Accepted 7 May 2008

Available online 21 May 2008

\section{Keywords:}

Cape Basin

Pliocene-Pleistocene

seismostratigraphy

palynology

sea level

Northern Hemisphere Glaciation

\begin{abstract}
A B S T R A C T
In this integrated study of seismostratigraphy and palynology we provide an insight into the depositional environment in the northern Cape Basin during the late Pliocene with respect to global climate changes. A well-pronounced succession of continuous high-amplitude reflectors characterizes the upper acoustic units off the coast of Southwest Africa. Among the seismic structures, unconformity NCB-B dated at 2.1 Ma represents a striking feature. The internal reflectors below in unit NCB-1c show toplap termination indicating stagnating deposition. In contrast, the reflectors above in unit NCB-1b onlap onto this interface, thus suggesting the return of a gentle increase in deposition. The observed reflector configurations and shifts in the location of the deposition centre correspond to a number of global and local events. The change from toplap to onlap reflector configuration corresponds to a transgressive period in eustatic sea level. Furthermore, the formation of unit NCB- $1 \mathrm{~b}$ coincides with a marked change of pollen assemblages indicating an intensified aridification of the Namibian hinterland and a loss of river discharge into the northern Cape Basin at about 2.1 Ma. Further, the onlap configuration of reflectors indicates an enhanced production and deposition, probably due to increased upwelling and an extension of upwelling filaments further seawards associated with enhanced wind stress as a result of intensification of Northern Hemisphere Glaciation. In summary, the seismic reflection pattern evidences a pronounced and sudden change of the deposition system in the latest Pliocene. Another marked climate step probably led to changes in composition and manner of transport of matter to the Cape Basin.
\end{abstract}

(c) 2008 Elsevier B.V. All rights reserved.

\section{Introduction}

The Benguela Current System (BCS) off south-western Africa has an essential impact on global climate because of its heat exchange and due to the upwelling related high productivity (Berger and Wefer, 1996 and references therein). Contributions to the heat transport from the Southern to the Northern Hemisphere come from the Antarctic Intermediate Water (AAIW) and the Agulhas Current (AC), both consisting of warm surface water from the Indian Ocean and entering the Cape Basin from the south. The southwards directed North Atlantic Deep Water (NADW) and cold Antarctic Bottom Water (AABW) enter the Cape Basin as undercurrents (e.g. Lutjeharms and Stockton, 1987).

As one of the major upwelling systems in the world the Benguela Upwelling System affects the atmosphere-ocean carbon cycle (Berger et al., 1996) and influences the local climate of southern Africa by restricting evaporation for onshore precipitation (Marlow et al., 2000). Upwelling off southwest Africa probably started during the midMiocene (Siesser, 1980), but intensified as part of the PliocenePleistocene climate transition (Marlow et al., 2000).

\footnotetext{
* Corresponding author. Tel.: +49 47148311885.

E-mail address: estella.weigelt@awi.de (E. Weigelt).
}

The late Cenozoic uplift of plateaus in southern Asia and the western Americas is regarded as an important forcing for the Plio-Pleistocene climate change on the northern hemisphere (Ruddiman and Kutzbach, 1989). Furthermore, the final closure of the Panama Gateway probably initiated the transition from a relatively warm era during the midPliocene to a globally cooler state during the Pleistocene. As a result, the global oceanic circulation system reorganized (Haug and Tiedemann, 1998), the Northern Hemisphere Glaciation (NHG) intensified more and more in the late Pliocene, and cyclic glacial-interglacial periods developed in the Pleistocene (e.g. Zachos et al., 2001 and references therein). In Antarctica in contrast, cooling and rapid expansion of continental icesheets are recorded since the earliest Oligocene, and a permanent ice cover has persisted since the middle Miocene in spite of a warmer period during the mid-Pliocene climate optimum (e.g. Zachos et al., 2001 and references therein).

In the late Pliocene, upwelling along the southwest African coast became more trade wind-controlled with enhanced advection of subAntarctic water masses into the Benguela Current System (Lange et al., 1999). An essential importance at this is the location of the Polar Front Zone (PFZ). It is the transition where cold, northward-flowing Antarctic waters meet and mix with the relatively warmer waters of the sub-Antarctic. The latitudinal position of the PFZ determines the 
location of atmospheric high-pressure cells over the South Atlantic. Changes in location and pressure gradient of the South Atlantic High induce changes in wind stress which in turn drive the upwelling strength and influence essentially the climate of southern Africa. Sedimentary samples provide evidence that the climate around Namibia became much drier since Miocene times (Ward and Corbett, 1990; Bremner and Willis, 1993). Studies on the vegetation of southern Africa indicate a northward shift of the PFZ between 3.1 and 2.2 Ma and afterwards a southward migration, accompanied by a further rapid desiccation in Namibia (Diekmann et al., 2003; Dupont et al., 2005).

Tectonic movements and eustatic sea level changes both formed and influenced the continental margin of Africa and the adjacent Cape Basin. Southern Africa underwent repeated asymmetrical epeirogenic uplift during the Cenozoic accompanied by a western tilt (Partridge and Maud, 1987; Gurnis et al., 1999 and references therein). The tectonic movements and resulting height of the relative sea level superpose with eustatic sea level fluctuations (Haq et al., 1987), which makes it difficult to establish sea level curves for this continent. The uplift of southern Africa even resulted in changes in the wind system and incisions of rivers and thus had an impact on the sediment dispersal (Bluck et al., 2007).

Those processes are documented in the sedimentary sequences along the continental margin off south-western Africa. On seismic reflection lines, these events are imaged in typical traces such as the configuration of layers, structures of mass movements or hiati. Furthermore, seismic profiles give a spatial picture of the location and shift of depocentres. However the reason for those changes cannot be deduced from seismics alone and a link to other parameters is necessary to identify the origin of those changes.

For this study we decided on an incorporation of palynological data to investigate the background for changes in deposition style and to set up a land-sea link. The pollen assemblages in the sediments indicate climate conditions which, in turn, impacted on other parameters such as sedimentary composition and hence density which we can identify in the seismic reflection pattern. We focus on the late Pliocene, which is a period of several distinguished cooling steps between 3.5-3.3 Ma, 2.8-2.5 Ma, and 2.0-1.7 Ma, influencing the evolution of the marine and terrestrial environment in and around southern Africa (Tiedemann et al., 1994; Marlow et al., 2000; DeMenocal, 2004; Dupont et al., 2005). We especially attend to a seismic unconformity at $2.1 \mathrm{Ma}$ indicating profound changes in deposition regime at the end of the Pliocene.

Our study aims at an insight into the depositional environment of the Cape Basin in regard to (1) global climate changes and interhemispheric coupling; and (2) the differentiation of eustatic sea level fluctuations and variations caused by tectonic movements.

\section{Materials and methods}

Our study is based on a combination of seismic reflection lines and drill site records from three ODP Leg 175 sites (Fig. 1). The studied Sites 1081, 1082, and 1083 are located under the northern part of the Benguela upwelling system. With a maximum depth of $580 \mathrm{mbsf}$ (meters below sea floor), the drilling sites recovered a mainly continuous organic-rich sedimentary section and offer an excellent record of the productivity history of the last 8.5 m.y. (since late Miocene) (Wefer et al., 1998). The sediments mainly consist of hemipelagic clays and oozes composed of varying amounts of diatoms, nannofossils, foraminifers and radiolarians. (Wefer et al., 1998). The upwelling related high sedimentation rates fluctuate around 10 cm/k.y. (e.g. Giraudeau et al., 2001; Berger et al., 2002) and density records reveal a cyclic variability, which is attributed to Milankovitch periods (Gorgas et al., 2001).

Palynology data are available from 1.8-3.4 Ma and provide a detailed model of the climate variations in the hinterland (Dupont et al., 2005;

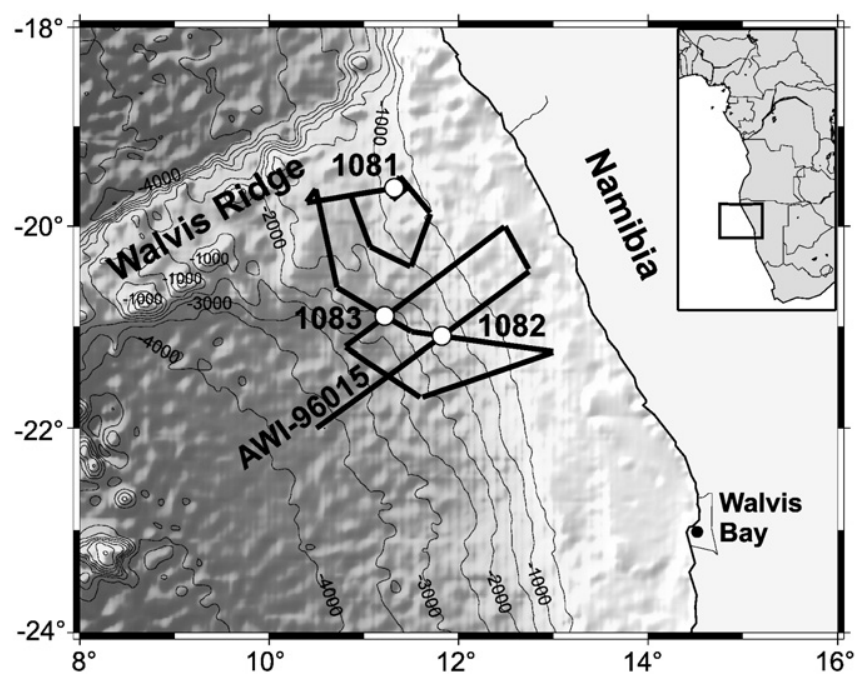

Fig. 1. Bathymetric map of the northern Cape Basin showing the locations of the seismic reflection lines (Weigelt and Uenzelmann-Neben, 2007) and ODP Leg 175 Sites 10811083 (Wefer et al., 1998). The annotated line AWI-96015 and Site 1082 are shown in Figs. 2 and 3.

Dupont, 2006). Seismic data image a well-pronounced reflection pattern of more than $2 \mathrm{~s}$ TWT (two-way traveltime) thickness, which corresponds to a penetration depth of more than $1 \mathrm{~km}$ below sea floor (Fig. 2). To correlate seismic data with sedimentary properties (Fig. 3), sonic logs calculated from the P-wave velocity logs were applied to convert the drill site data from depth domain into two-way traveltime domain (Weigelt and Uenzelmann-Neben, 2007). The dating of seismic horizons relies on the interpolated age model of Berger et al. (2002), which is derived from nannofossil stratigraphy and paleomagnetic reversals. On the basis of the incorporation of site and seismic data, the depth resolution of seismic reflectors represents $10 \mathrm{~m}$ and the temporal resolution converts to 8-15 k.y. depending on the sedimentation (Weigelt and Uenzelmann-Neben, 2007). Seismic units (Figs. 2a and 4) were defined on the base of reflection pattern, reflector configuration and vertical P-wave velocity changes (Weigelt and Uenzelmann-Neben, 2007).

To define a depositional model for the upper seismic units we computed isopach maps of the unit's sedimentation rates (Fig. 5), which enabled a comparable illustration of the units' feature and development. For this purpose we tracked the units base reflectors, computed the units thickness in milliseconds TWT, and converted it into metres applying a mean Vp-velocity from core/log data of Site 1082 (Wefer et al., 1998) for the corresponding depth range of the units (Table 1). Sedimentation rates were calculated. We defined the unit depocentres by the outline of the root mean square (RMS) value of the unit's sedimentation rates (Fig. 5). From their shape and location relative to the continental slope we deduced the origin and the route of transport of the deposited material. RMS-values for the unit's accumulation rate were computed by the multiplication of the RMSsedimentation rate with the area of the outlined depocentres (Table 1).

\section{Results}

The seismic records show sub-parallel layers of closely spaced, continuous high-amplitude reflectors, which blanket the Namibian continental slope (Fig. 2a). These layers are thickest on a terrace-like feature on the upper slope and form a wedge thinning towards the shelf break. Further downslope another break interrupts the dip of the continental margin, and here, the sedimentary layers are displaced by vertical faults (Fig. 2a, CDPs 5300-6000).

A striking unconformity (NCB-B) dated at 2.1 Ma cuts the sub parallel reflector configuration below the shelf break (Fig. 4, CDPs 8800-9300). 
a

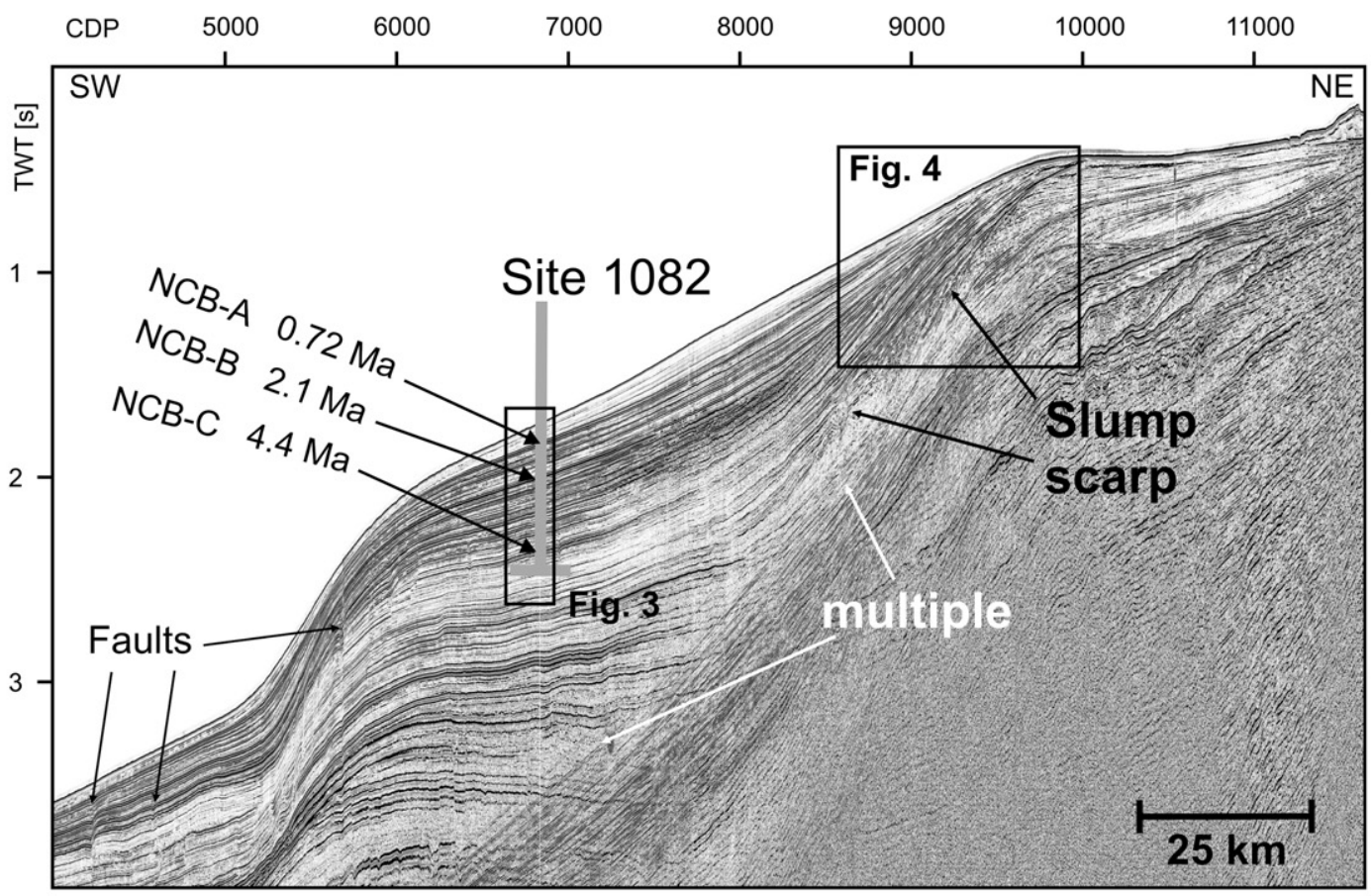

b

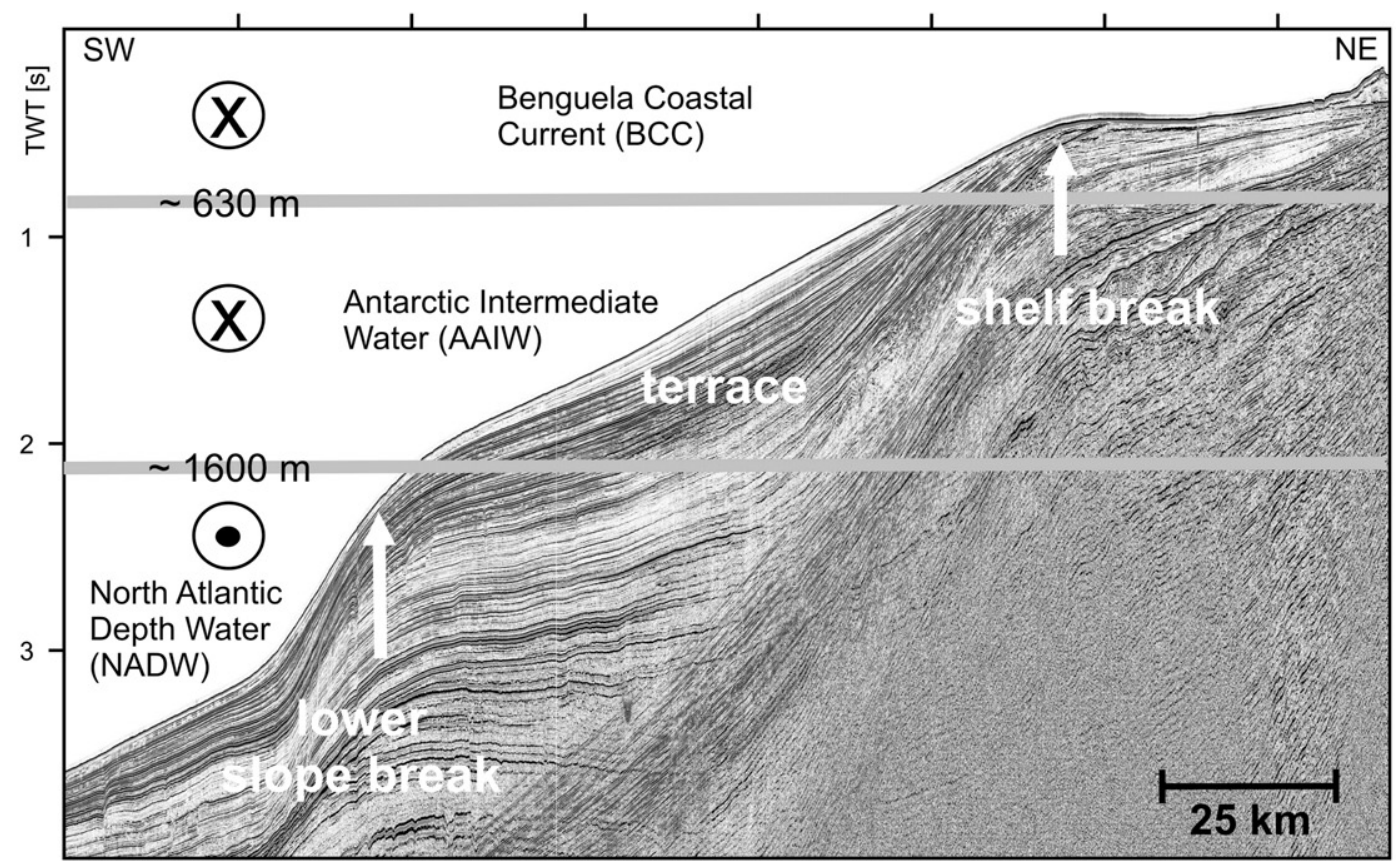

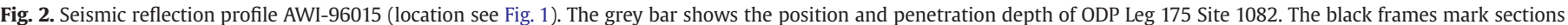

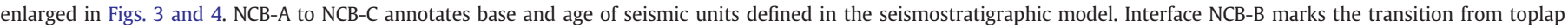

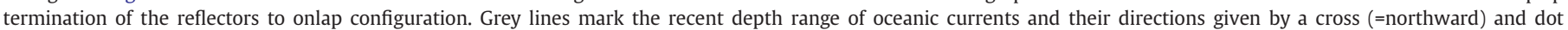
(=southward).

The internal reflectors of the unit below (NCB-1c) show toplap termination, whereas the reflectors above (NCB-1b) onlap onto this interface. This is an indication of non-deposition on the upper slope before $2.1 \mathrm{Ma}$ (late Pliocene). In contrast, the unit above the unconformity shows indications for a gentle increase of deposition. Since we can identify this Late Pliocene unconformity $250 \mathrm{~km}$ along the margin of the Northern Cape Basin we infer a large regional change in deposition regime.

We gain affirmation from the synthesis of seismic records and TWT-transformed drill site information of ODP Site 1082, which shows contemporaneous, and marked changes in $\mathrm{CaCO}_{3}$ (Calcium Carbonate),
TOC (Total Organic Carbon), sedimentation rate, and pollen assemblages (Fig. 3). So, at $2.1 \mathrm{Ma}$ the sedimentation rate drops clearly from $\sim 13$ to $\sim 8 \mathrm{~cm} / \mathrm{k} . \mathrm{y}$. (Berger et al., 2002). The content in $\mathrm{CaCO}_{3}$ lowers from more than $30 \mathrm{wt} . \%$ to only $15 \mathrm{wt} . \%$ between 2.1 and $1.5 \mathrm{Ma}$. Also, in the same time period TOC concentrations are lower, indicating a loss of terrigenous input due to aridification of hinterland rather than by a change of ocean currents (Berger et al., 2002). This assumption is supported by palynological investigations (Dupont et al., 2005), which reveal a distinct drop in pollen accumulation rate from 50-60 pol/a/ $\mathrm{ccm}$ (pollen per year per cubic centimetre) in older layers to $8 \mathrm{pol} / \mathrm{a} /$ 


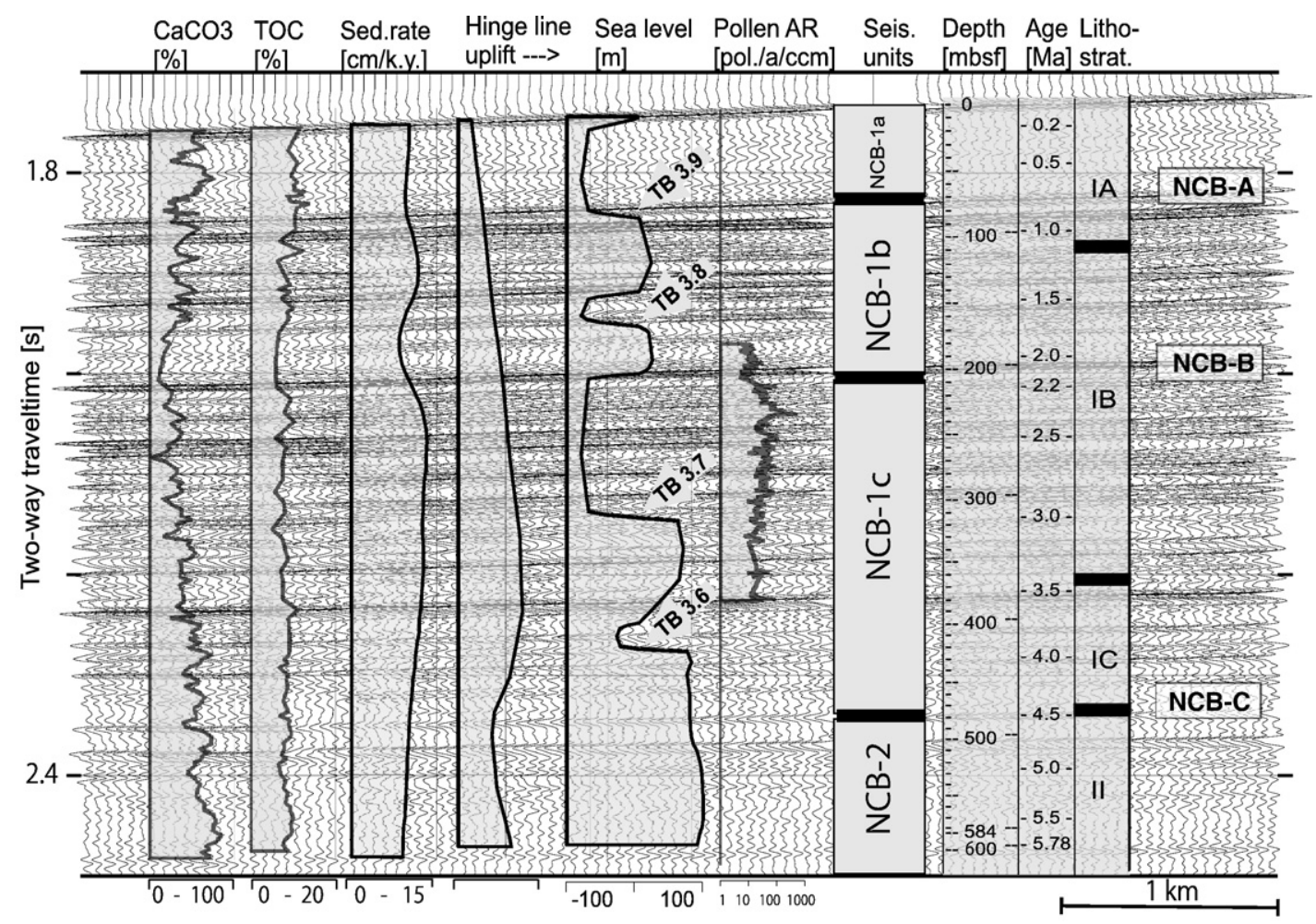

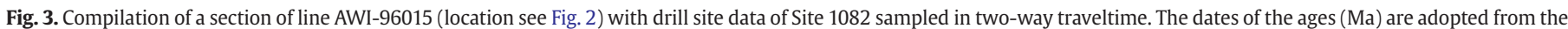

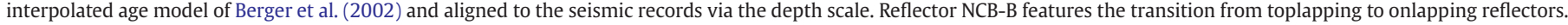

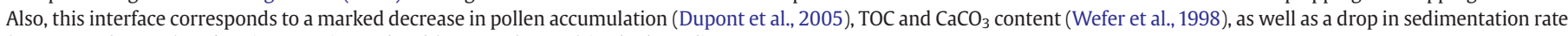
(Berger et al., 2002) and an increase in sea level (Haq et al., 1987) in the late Pliocene.

$\mathrm{ccm}$ on average after $2.1 \mathrm{Ma}$ (Fig. 6). Further, not only the total pollen influx decreases dramatically since $2.1 \mathrm{Ma}$, also the ratio between terrestrial and marine palynomorphs drops (Fig. 6). An increased production of cysts would not have caused a drop in pollen influx. The dinocyst flux shows no strong decline at 2.1 Ma but fluctuates around the same levels as before. This marked reduction of pollen input into the ocean is interpreted as the result of loss of a perennial river discharge, in turn indicating a change of hinterland climate from humid to drier conditions in the late Pliocene and a shift of the Polar Front Zone towards the south (Dupont et al., 2005).

Eustatic sea level variations also correlate with the change in reflector configuration (Fig. 3). The interface NCB-B matches the transition from the low stand at the end of the third order sea level cycle TB3.7 to the rising sea level at the start of TB3.8 (Haq et al., 1987). For all other 3rd order cycles since the Pliocene such a correspondence cannot be observed. The isopach maps of the seismic unit sedimentation rates show a general concentration of the deposition centre on the upper slope of the margin (Fig. 5). The maps reveal a shift of deposition centres varying with time:

(1) Between the late Miocene and early Pliocene (>10 Ma-4.5 Ma) unit NCB-2 shows mainly along-slope deposition centres spanning from the south-eastern flank of the Walvis Ridge to the southern end of the investigated area (Fig. 5a). The sedimentary layers wedge out upslope just below the shelf break. The seismic sections reveal numerous slump scarps (Fig. 2a) indicating a period of strong mass movements (Weigelt and Uenzelmann-Neben, 2007).

(2) In the early to late Pliocene (4.5-2.1 Ma) (Fig. 5b) the depocentre is concentrated south of $20^{\circ} \mathrm{S}$ on the upper slope of the Namibian margin. Furthermore, a large part of the outer shelf is covered and indicates an input from the shelf and land. On the southern flank of the Walvis Ridge the sedimentation rates are clearly smaller indicating no appreciable input from the ridge to the northernmost Cape Basin.
(3) For the middle to the late Pliocene (2.1-0.72 Ma) (Fig. 5c) we record a relocation of the sedimentary bulk downslope and southwards. This unit is thickest on the upper third of the slope but pinches off more than $12 \mathrm{~km}$ seawards of the shelf break. Consequently, there is a lack of sediments during this period on the uppermost slope and outer shelf indicating a loss of shelf and land-derived deposits.

(4) Since the middle Pleistocene $(<0.72 \mathrm{Ma}$ ) (Fig. $5 \mathrm{~d}$ ) the deposition centre concentrates in a strip along the upper slope. A large part of the outer shelf is covered. Seawards, and west of the lower slope break the sedimentary thickness decreases continuously.

\section{Discussion}

The marked change in reflector configuration evidences strong modifications of the depositional environment in the northern Cape Basin during the latest Pliocene. We observed a distinct change from toplapping reflectors to onlapping reflectors on the upper slope indicating a steady decrease and finally non-deposition by $2.1 \mathrm{Ma}$, after which time deposition restarted. The resulting seismic unconformity NCB-B corresponds to a number of events that we suggest to be in link with the intensification of the NHG.

\subsection{Eustatic sea level fluctuations}

The observed change in reflector configuration corresponds very well to a sea level transgression at 2.1 Ma as recorded by Haq et al. (1987) in the 3rd order cycle TB3.7 (Fig. 3). Since the Pliocene, five short-term cycles (TB3.5 to TB3.9) of eustatic sea level changes are recorded (Haq et al., 1987). Such fluctuations leave a typical trace in the seismic reflector configuration in such a way that toplapping reflectors indicate a seawards retreat of the sediment deposition, which is interpreted as a sea level regression. In contrast, onlapping reflectors characterize a landwards shift of deposition, which is regarded as a sea level transgression (Vail et al., 1977). In fact, the 


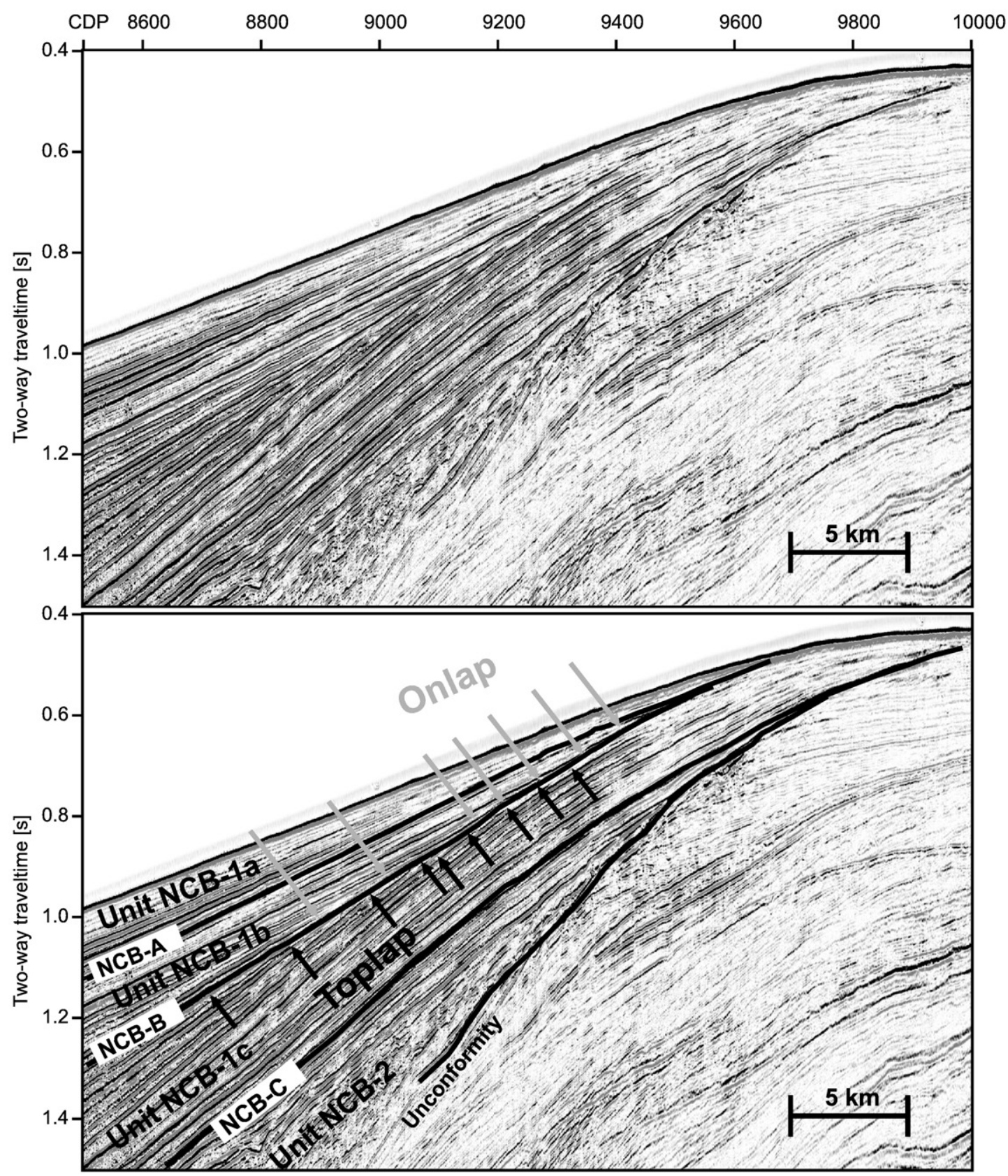

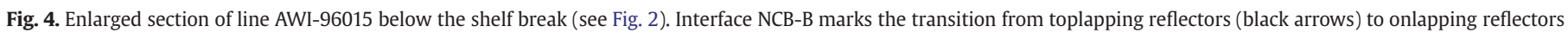
above (grey arrows).

marked transition from toplap to onlap configuration between the layers NCB-1c below to NCB-1b above suits the criteria for a rising sea level in the late Pliocene. But a conundrum has to be elucidated: Eustatic cycles are considered to be controlled by growth and decay of continental ice sheets due to climate changes (Vail et al., 1977; Miller et al., 2005 and references therein), and thus the onlap configuration in unit NCB-1b would indicate a relatively warm period. In contrast a long-term global cooling since the Pliocene has been registered (e.g. Zachos et al., 2001 and references therein) which contradicts any rise of sea level related to ice volume.

\subsection{Tectonic}

A regional relative fluctuation of sea level can also be caused by uplift, tilt or subsidence of the continental margin due to tectonic processes. Because Africa has been rising since Eocene time (Partridge and Maud, 1987) it is difficult to establish sea level curves for this continent. Wigley and Compton (2006) infer to a downwarping of the western margin in the late Pliocene from the increase of terrigenous sediments on the shelf and from the incision of the Cape Canyon. That would help to explain our indications of a transgression in times of generally increasing ice volume. To compare seismic units with tectonic movements during the Pliocene we rely on data of a relatively simple epirogenesis curve of the hinge line uplift (Fig. 3). This curve shows a continuous hinge line lowering since about 3.5 Ma (Siesser, 1978), which implicates a regional continuous rise of relative sea level since the middle Pliocene. For those reasons we suggest only a minor bearing of tectonic causes on short-term sea level fluctuations.

\subsection{Upwelling}

Comparing seismic data with distinct variations in sedimentary properties we suppose a further mechanism for the shift in sediment supply during the late Pliocene. 

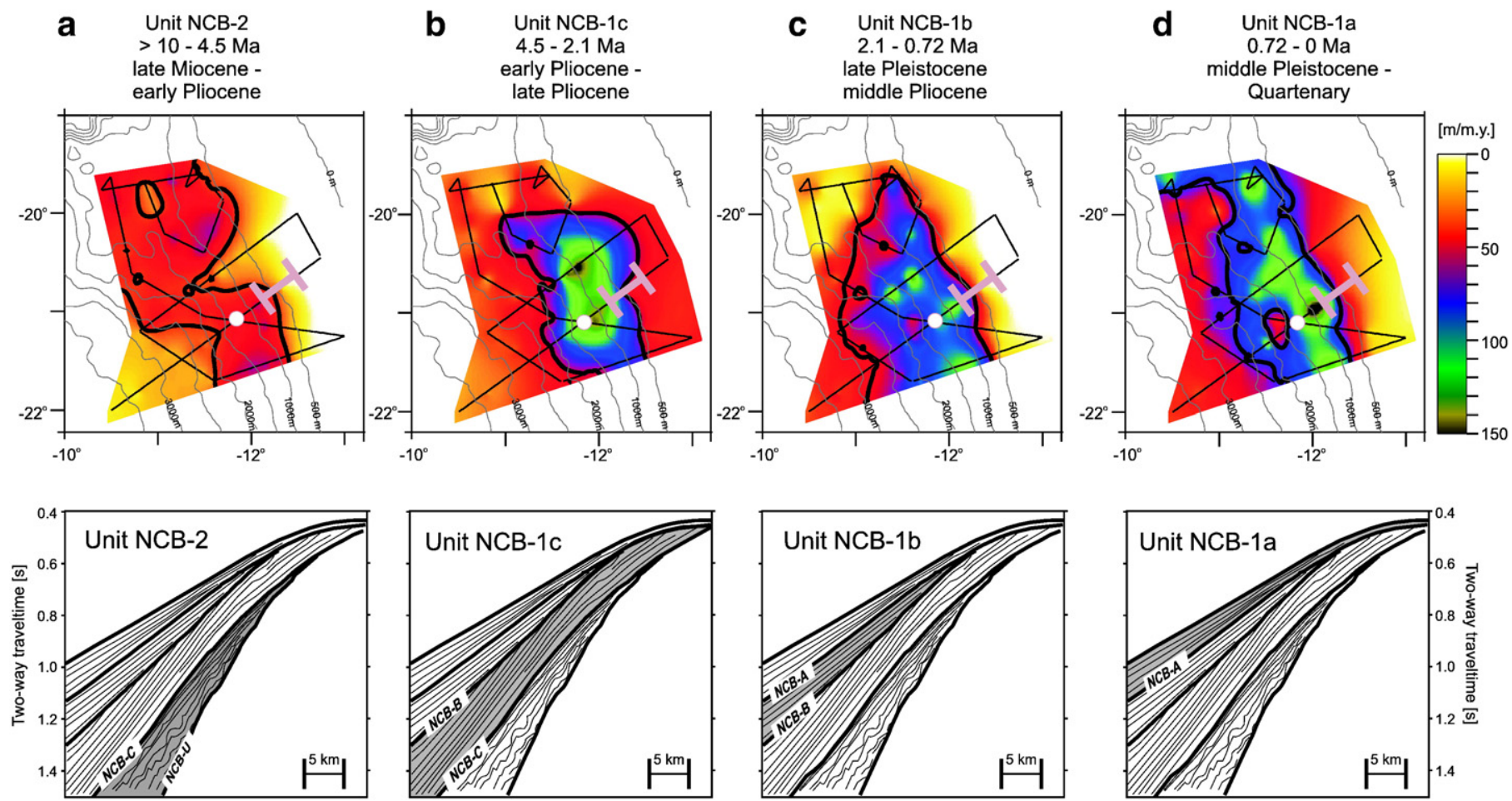

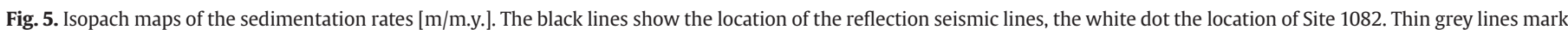

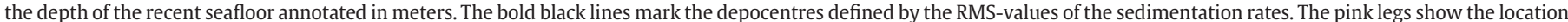

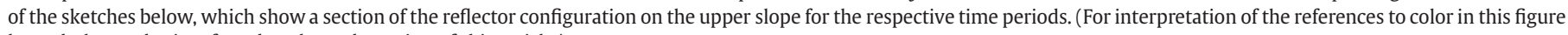
legend, the reader is referred to the web version of this article.)

Especially at Site 1082, a change in pollen assemblage shows synchrony with the interface NCB-B (Fig. 3) indicating variation in the amount and transport direction of the deposited matter. The drop of pollen influx and change in relative abundance of palynomorphs (Fig. 6) reveals a decline of regular river discharge into the northern Cape Basin which Dupont et al. (2005) suggested to be the result of drier climate conditions in the hinterland since $2.1 \mathrm{Ma}$. Patterns of sediment accumulation reveal a peak of more than $16 \mathrm{~cm} / \mathrm{k}$.y. centred between 2 and $2.5 \mathrm{Ma}$, and the highest input of biogenic opal, but at the same time a significant decrease of carbonate mass accumulation rate (Giraudeau et al., 2001). The intensification of the NHG at the end of the Pliocene probably led to stronger thermal gradients between high- and low-latitudes. With it, the wind stress strengthened and in turn resulted in increased upwelling and aridity in the continent (e.g. Dupont et al., 2005; Dupont 2006 and references therein). Additionally, the production of NADW was reduced during glacials which in turn influenced the production rate of AAIW (Tiedemann et al., 1994). This scenario in parts seems to be in agreement with our observations but some peculiarities remain:

Congruently, the isopach map of unit NCB-1c shows that sediments cover a large part of the outer shelf, which we interpret as a reliable input from the shelf and landside during its formation before 2.1 Ma (Fig. 5b). The observed toplapping reflectors in the seismic sections indicate a stepwise stagnation of deposition as early as the late Pliocene (Fig. 5b below). In unit NCB-1b any deposits lack on the outer shelf, whereas the deposition centre is clearly retreated to the slope, which we regard as a loss of land-derived matter (Fig. 5c). Coeval, we observe the onlapping structure in unit NCB-1b that we suggest to be the result of increasing upwelling-related productivity and deposition as well as a transport of upwelling filaments seawards. The crux of the matter is that upwellingrelated productivity is mainly concentrated in shallow waterdepths on the shelf and shelf break and decreases seawards (e.g. Lutjeharms and Stockton, 1987; Wefer et al., 1998). So, if upwelling intensified due to enhanced wind stress, we would expect a thicker cover of sediments all over the upper slope and shelf area too. This is not the case. Unit NCB-1b reaches only up to the upper third of the slope (Fig. 5c). No sedimentary cover further upslope exists, nor on the shelf, that was established between 2.1 and 0.72 Ma which indicates an influence of currents leading to increased deposition on the middle slope.

\subsection{Currents}

The seismic unconformity NCB-B is indeed located on the upper slope and corresponds to the modern zone between the Benguela Costal Current (BCC) and the Antarctic Intermediate Water (AAIW) (Lutjeharms and Stockton, 1987) (Fig. 2b) and might have been configured by changes of these northbound currents. The divergent shape of the reflectors downslope can be explained by the left bulge depositions of northbound currents on the southern Hemisphere. Several studies showed that the marine currents changed with times (Bremner and Willis, 1993). Investigations of oceanographic currents revealed a shift of the PFZ northwards between 2.9 and 2.2 Ma (Diekmann et al., 2003). During this period Lange et al. (1999) suggested an increased advection of subAntarctic water masses into the Benguela system as marked by the Matuyama diatom maximum. At about 2.1 Ma the southern ocean component of diatom assemblages disappeared and the diatom abundance maximum came to an end. Still, the post maximum diatom abundance is higher than in the mid-Pliocene. This indicates a production due to increased wind-driven upwelling (Lange et al., 1999; Marlow et al., 2000; Berger et al., 2002; Dupont et al., 2005). Congruently, the isopach maps of sedimentation rate show a concentration of deposits in the middle of the observed area before $2.1 \mathrm{Ma}$ (Fig. 5b). Later, in contrast, the sediment distribution stretches more along the margin increasing towards the south (Fig. 5c). This could evidence the increasing influence of upwelling, which we suggest led to a more evenly distributed deposition along the slope.

\section{Conclusion}

Our seismostratigraphic study of the northern Cape Basin reveals a marked unconformity in the seismic reflection pattern, named 
Table 1

Compilation of sedimentary units, their ages, RMS-thickness, RMS-sedimentation rates, and RMS-accumulation rates, base reflectors of units, events and interpretation

\begin{tabular}{|c|c|c|c|c|c|c|c|c|}
\hline $\begin{array}{l}\text { Seismic } \\
\text { unit }\end{array}$ & $\begin{array}{l}\text { Unit age } \\
\text { (Ma) }\end{array}$ & $\begin{array}{l}\text { RMS-thickness } \\
\text { in }(\mathrm{ms}) \text { and }(\mathrm{m}) \\
\text { and } \mathrm{Vp} \text { in }(\mathrm{km} / \mathrm{s})\end{array}$ & $\begin{array}{l}\text { RMS- } \\
\text { sedimentation } \\
\text { rates (m/My) }\end{array}$ & $\begin{array}{l}\text { RMS-area } \\
\left(\mathrm{km}^{2}\right) \\
\text { Accumul. rates } \\
\left(10^{11} \mathrm{~m} / \mathrm{My}\right)\end{array}$ & $\begin{array}{l}\text { Base } \\
\text { reflector }\end{array}$ & $\begin{array}{l}\text { Internal } \\
\text { configuration }\end{array}$ & Interpretation of seismic & Events (e.g. sea level, climate, currents) \\
\hline NCB-1a & $0.0-0.72$ & $\begin{array}{l}66 \\
44 \\
1.51\end{array}$ & 61 & $\begin{array}{c}271 \times 105 \\
17\end{array}$ & NCB-A & $\begin{array}{l}\text { Subparallel } \\
\text { continuous } \\
\text { reflectors. }\end{array}$ & $\begin{array}{l}\text { Deposition towards the } \\
\text { upper slope and outer } \\
\text { shelf. } \\
\text { Evenly spread/cover of } \\
\text { modern deposits on } \\
\text { margin. }\end{array}$ & Onset of glacial-interglacial cycles. \\
\hline NCB-1b & $0.72-2.1$ & $\begin{array}{l}82 \\
63 \\
1.53\end{array}$ & 46 & $\begin{array}{c}246 \times 117 \\
13\end{array}$ & NCB-B & $\begin{array}{l}\text { Onlapping, } \\
\text { continuous } \\
\text { high-amplitude } \\
\text { reflectors. } \\
\text { Wedge below } \\
\text { shelf break. }\end{array}$ & $\begin{array}{l}\text { Renewed deposition } \\
\text { towards the upper slope. }\end{array}$ & $\begin{array}{l}\text { Sea level transgression with short regressive } \\
\text { pulse (Haq et al., 1987). } \\
\text { Onset of Benguela provincialism into a } \\
\text { northern and southern sedimentary regime } \\
\text { (Giraudeau et al., 2001). } \\
\text { Desiccation of hinterland and loss of riverine } \\
\text { input associated with increasing upwelling and } \\
\text { deceasing sea surface temperature } \\
\text { (Dupont et al., 2005). } \\
\text { South shift of PFZ (e.g. Diekmann et al., 2003). } \\
\text { Transition to cold mode of trade wind } \\
\text { controlled upwelling (Lange et al., 1999). }\end{array}$ \\
\hline NCB-1c & $2.1-4.5$ & $\begin{array}{l}151 \\
127 \\
1.68\end{array}$ & 53 & $\begin{array}{c}197 \times 117 \\
12\end{array}$ & NCB-C & $\begin{array}{l}\text { Toplapping, } \\
\text { continuous, } \\
\text { high-amplitude } \\
\text { reflectors. } \\
\text { Increasing into } \\
\text { fill center of } \\
\text { terrace. }\end{array}$ & $\begin{array}{l}\text { Decreasing input from } \\
\text { land side. } \\
\text { Phase out of deposition } \\
\text { seawards from upper } \\
\text { slope to middle slope. } \\
\text { Non-deposition on upper } \\
\text { slope. }\end{array}$ & $\begin{array}{l}\text { Sea level regression (Haq et al., 1987). } \\
\text { Matuyama diatom maximum. } \\
\text { Between 2.9-2.2 Ma northwards shift of } \\
\text { PFZ (Diekmann et al., 2003). } \\
\text { During the northshift of PFZ enhanced } \\
\text { advection of sub-Antarctic water masses into } \\
\text { the Benguela system (Lange et al., 1999). } \\
\text { Coupled to PFZ shift also the westerly winds } \\
\text { moved northwards which caused increased } \\
\text { rainfall in winter and a more humid hinterland } \\
\text { (Dupont et al., 2006). }\end{array}$ \\
\hline NCB-2 & $4.5 \rightarrow 10$ & $\begin{array}{l}182 \\
170 \\
1.87\end{array}$ & 31 & $\begin{array}{c}256 \times 117 \\
9\end{array}$ & NCB-U & $\begin{array}{l}\text { Chaotic } \\
\text { reflection } \\
\text { pattern. } \\
\text { Slump scarps. } \\
\text { Wedge below } \\
\text { shelf break. }\end{array}$ & $\begin{array}{l}\text { Erosion above shelf } \\
\text { break and slumping } \\
\text { towards the upper slope. }\end{array}$ & $\begin{array}{l}\text { Sea level high with only short regressive pulse } \\
\text { (Haq et al., 1987). } \\
\text { Lithostratigr. boundary Ic/II (Wefer et al., 1998). }\end{array}$ \\
\hline
\end{tabular}

NCB-B, and defined by the transition from toplapping reflectors to onlapping reflectors. This is the most remarkable feature in the Pliocene/Pleistocene sedimentary wedge on the upper slope of the Namibian margin and indicates non-deposition before 2.1 Ma, and an increased supply of matter afterwards. We found the seismic unconformity to coincide with a transgression of eustatic sea level in the late Pliocene corresponding to investigations of Haq et al. (1987). Due to the tectonic movements of southern Africa however, we suggest only a weak impact of global sea level changes to the unconformities and depositional pattern in the Cape Basin. Mainly the interface corresponds to three changes that all are related to climate and ocean current variations in the latest Pliocene. Firstly, the abundance and composition of palynomorphs suggest a distinguished strengthened aridification of the Namibian hinterland at 2.1 Ma related to upwelling intensification as a result of a shift of PFZ southwards (Dupont et al., 2005; Dupont, 2006). Secondly, the portion of river-derived sediments reduced and at the same time upwelling-related deposition increased which we propose to be manifested in the changing reflector configuration from toplapping before $2.1 \mathrm{Ma}$ to onlapping later. Thirdly, in correspondence to changes in the ocean currents, the deposition centres moved from the upper slope and outer shelf to the lower slope at about 2.1 Ma (Fig. 5b, c), Between 2.6 and $2.1 \mathrm{Ma}$ a diatom maximum indicates the advection of AAIW, whereas diatom assemblages indicate a production due to increased wind-driven upwelling afterwards (Lange et al., 1999; Berger et al., 2002).

It is thought that the final closure of the Panama Gateway provoked a chain reaction in atmospheric and ocean circulation patterns which forced the development of the NHG with a major intensification between 3.2 and 2.7 Ma (e.g. Maslin et al., 1998; Haug and Tiedemann, 1998 and references therein). This cooling step probably modified the deposition system in the Cape Basin too. A close interaction between eustatic sea level fluctuations, upwelling strength, and currents variations was responsible for the formation of seismic units. The seismic 


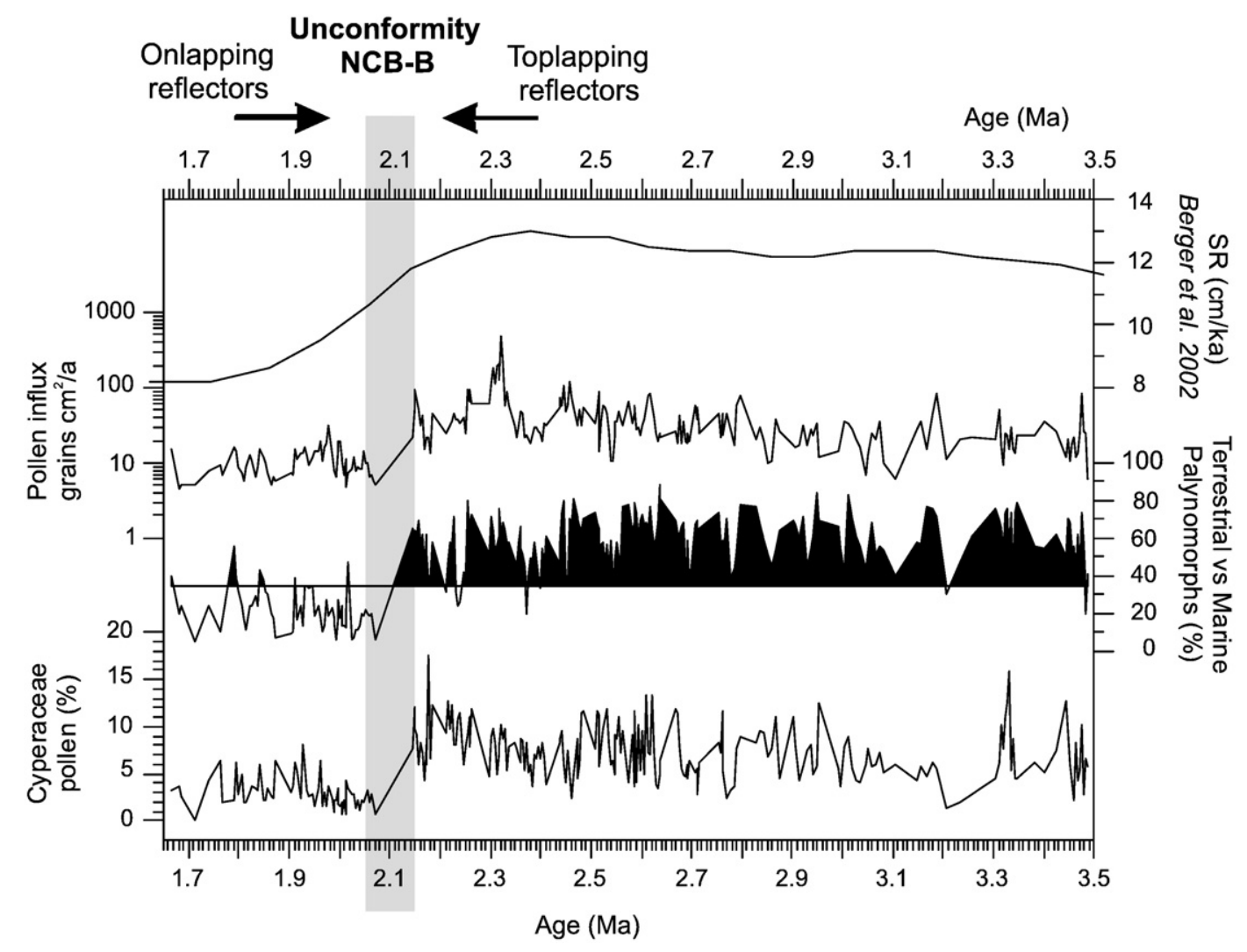

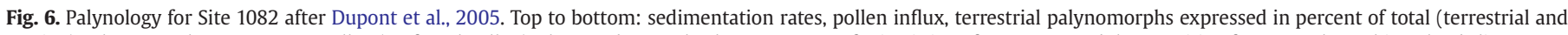

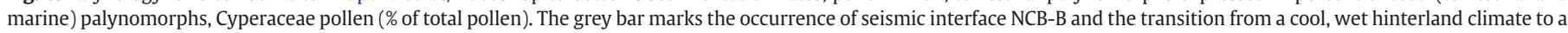
drier and warmer setting in the late Pliocene.

unconformity indicates a significant change in deposition environment in the latest Pliocene around 2.1 Ma. This age is later than the globally recognized cooling step between 2.7 and 2.5 Ma which is associated with the intensification of the NHG (DeMenocal, 2004). We suggest that the reversal of seismic reflector configuration in correspondence with palynological data indicates another concise climate change in latest Pliocene.

\section{Acknowledgements}

We are grateful for the support and assistance of the officers and crew of RV Meteor on cruise 34/1, Prof. U. Bleil (chief scientist) and the team of Ocean Drilling Program (ODP) Leg 175. This research used samples and/or data provided by the ODP. The U.S. National Science Foundation (NSF) sponsors the ODP and participating countries under management of Joint Oceanographic Institutions (JOI), Incorporation. The Deutsche Forschungsgemeinschaft under contract number Ue 49/ 8 provided funds for this research. Richard Crawford kindly improved the English. We further acknowledge the helpful comments of the reviewers P. Giresse and B. Bluck, and the editor P.A. Pirazzoli. This is AWI contribution number awi-nxxxxx.

\section{References}

Berger, W.H., Lange, C.B., Wefer, G., 2002. Upwelling history of the Benguela-Namibia System: a synthesis of Leg 175 results. In: Wefer, G., Berger, W.H., Richter, C. (Eds.), Proc. Ocean Drill. Program Sci. Results, College Station, Texas, vol. 175, pp. 1-103.

Berger, W.H., Wefer, G., 1996. Expeditions into the past: paleoceanographic studies in the South Atlantic. In: Wefer, G., Berger, W.H., Siedler, G., Webb, D.J. (Eds.), The South Atlantic: Present and Past Circulation. Springer Verlag, Berlin, pp. 363-410.

Berger, W.H., Bickert, T., Yasuda, M.K., Wefer, G., 1996. Reconstruction of atmospheric CO2 from the deep-sea record of Ontong Java Plateau: the Milankovitch chron. Geologische Rundschau 85, 466-495.
Bluck, B.J., Ward, J.D., Cartwright, J., Swart, R., 2007. The Orange River, southern Africa: an extreme example of a wave-dominated sediment dispersal system in the South Atlantic Ocean. Journal of the Geological Society (London) 164, 341-351.

Bremner, J.M., Willis, J.P., 1993. Mineralogy and geochemistry of the clay fraction of sediments from the Namibian continental margin and the adjacent hinterland. Marine Geology 115, 85-116.

DeMenocal, P.B., 2004. African climate change and faunal evolution during the Pliocene-Pleistocene. Earth Planetary Science Letters 220, 3-24.

Diekmann, B., Fälker, M., Kuhn, G., 2003. Environmental History of the south-eastern South Atlantic since the middle Miocene: evidence from the sedimentological records of ODP Sites 1088 and 1092. Sedimentology 50, 511-529.

Dupont, L.M., Donner, B., Vidal, L., Pérez, E.M., Wefer, G., 2005. Linking desert evolution and coastal upwelling: Pliocene climate change in Namibia. Geology 33 (6) 461-464.

Dupont, L.M., 2006. Late Pliocene vegetation and climate in Namibia (southern Africa) derived from palynology of ODP Site 102. Geochemistry, Geophysics, Geosystems 7, Q05007. doi:10.1029/2005GC001208.

Giraudeau, J., Meyers, P.A., Christensen, B.A., 2001. Accumulation of organic and inorganic carbon in Pliocene-Pleistocene sediments along the SW African margin. Marine Geology 180, 49-69.

Gorgas, T.J., Kronen Jr., J.D., Wilkens, R.H., 2001. Data report: sedimentation rates from Milankovitch periodicity in log and GRA bulk density records off Southwest Africa, Sites 1081, 1082, and 1084. In: Wefer, G., Berger, W.H., Richter, C. (Eds.), Proc. Ocean Drill. Program Sci. Results, College Station, Texas, vol. 175, pp. 1-23.

Gurnis, M., Mitrovica, J.X., Ritsema, J., van Heijst, H.J., 1999. Constraining mantle density structure using geological evidence of surface uplift rates: the case of the African Superplume. Geochemistry, Geophysics, Geosystems 1 1999GC000035.

Haq, B.U., Hardenbol, J., Vail, P.R., 1987. Chronology of fluctuating sea levels since the Triassic. Science 235, 1156-1167.

Haug, G.H., Tiedemann, R., 1998. Effect of the formation of the Isthmus of Panama on Atlantic Ocean thermohaline circulation. Nature 393, 673-676.

Lange, C.B., Berger, W.H., Lin, H.-L., Wefer, G., Shipboard Scientific Party Leg 175, 1999 The early Matuyama diatom maximum off SW Africa, Benguela Current System (ODP Leg 175). Marine Geology 161, 93-114.

Lutjeharms, J.R.E., Stockton, P.L., 1987. Kinematics of the upwelling front off southern Africa. South African Journal of Marine Science 5, 35-49.

Marlow, J.R., Lange, C.B., Wefer, G., Rosell-Melè, A., 2000. Upwelling intensification as part of the Pliocene-Pleistocene climate transition. Science 290, 2288-2291.

Maslin, M.A., Li, X.S., Loutre, M.F., Berger, A., 1998. The contribution of orbital forcing to the progressive intensification of Northern Hemisphere Glaciation. Quaternary Science Reviews 17, 411-426. 
Miller, K.G., Kominz, M.A., Browning, J.V., Wright, J.D., Mountain, G.S., Katz, M.E Sugarman, P.J., Cramer, B.S., Christie-Blick, N., Pekar, S.F., 2005. The Phanerozoic record of Global sea-level change. Science 310, 1293. doi:10.1126/science.1116412.

Partridge, T.C., Maud, R.R., 1987. Geomorphic evolution of the southern Africa since the Mesozoic. South African Journal of Geology 90, 179-208.

Ruddiman, W.F., Kutzbach, J.E., 1989. Forcing of the late Cenozoic Northern Hemisphere climate by plateau uplift in southern Asia and the American west. Journal of Geophysical Research 94 (D15), 18409-18427.

Siesser, G.W., 1978. Leg 40 Results in relation to continental shelf and onshore geology. DSDP Init. Rep., pp. 965-979.

Siesser, G.W., 1980. Late Neogene origin of the Benguela upwelling system off northern Namibia. Science 208, 283-285.

Tiedemann, R., Sarntheim, M., Shackleton, N.J., 1994. Astronomical timescale for the Pliocene Atlantic d018 and dust flux records of the Ocean Drilling Program Site 659. Paleoceanography 9, 619-638.
Vail, P.R., Mitchum Jr., R.M., Todd, R.G., 1977. Seismic stratigraphy and global changes of sea level. In: Payton C.E., Seismic stratigraphy - Applications to Hydrocarbon Exploration. Am. Assoc. Pet. Geol., Memo., vol. 26, pp. 49-212.

Ward, J.D., Corbett, I., 1990. Towards an age of the Namib. In: Seely, M.K. (Ed.), Ecology: 25 Years of Namib Research. Transvaal Museum Monograph, vol. 7, pp. 17-26.

Wefer, G., Berger, W.H., Richter, C., et al., 1998. Proceedings of Ocean Drilling Program, Initial Reports, vol. 175. College Station, Texas, p. 577.

Weigelt, E., Uenzelmann-Neben, G., 2007. Early Pliocene basic change of deposition style in the Cape Basin, southeastern Atlantic. Geological Society of America Bulletin 119 (7), 1004-1013. doi:10.1130/B25972.1.

Wigley, R.A., Compton, J.S., 2006. Late Cenozoic evolution of the outer continental shelf at the head of the Cape Canyon, South Africa. Marine Geology 226, 1-23. doi:10.1016/j.margeo.2005.09.015.

Zachos, J., Pagani, M., Sloan, L., Thomas, E., Billups, K., 2001. Trends, rhythms, and aberrations in global climate 65 Ma to present. Science 292, 686-693. 